\title{
THE RELATIONSHIP BETWEEN THE NUMERICAL ABILITY, MATHEMATICAL CONNECTIONS ABILITY, AND CLASSMATES LEARNING INTERACTION WITH MATH LEARNING OUTCOMES OF SMAN 2 BANGUNTAPAN
}

\author{
Ma'rifatun Khoiriyaha ${ }^{a}$, Sunaryo $^{\mathrm{b}}$ \\ Program Studi Pendidikan Matematika Universitas Ahmad Dahlan \\ Jalan Ring Road Selatan, Tamanan, Banguntapan, Bantul Yogyakarta \\ aripha.marifa@gmail.com, ${ }^{\text {b }}$ sunaryo.bener@yahoo.com
}

\begin{abstract}
Many factors are associated with mathematics learning outcomes. Numerical ability, mathematical connections ability and classmates learning interactions were related to student learning outcomes. Therefore, this study aimed to determine whether there is a relationship between the numerical ability, mathematical connections ability, and classmates learning interactions with math learning outcomes of students class XI IPA in even semester of SMAN 2 Banguntapan in Academic Year 2015/2016. The population in this study were students of class XI IPA at SMAN 2 Banguntapan Bantul in Academic Year 2015/2016 consisting of four classes, are class XI IPA 1, XI IPA 2 IPA 3 XI, and XI IPA 4 by the total of students by 100 students. Class XI IPA 3 was selected as a sample class using random sampling techniques, consisting of 27 students. Data collection techniques are done with the test method to determine the numerical ability, mathematical connections ability, and mathematics learning outcomes, the questionnaire method to determine the classmates learning interactions. To test instruments using validity, reliability and power difference. After the data collected, analyze prerequisite tests including normality test, independence, and linearity. Data analysis for hypothesis testing using product-moment correlation analysis and multiple linear regression analysis. The results showed that there is a positive and significant correlation between the numerical ability, mathematical connections ability, and classmates learning interactions with math learning outcomes by $F_{\text {cal }}=3,327$ and $F_{\text {table }}=3,028$, so $F_{\text {cal }}>F_{\text {table }}$. Multiple correlation coefficient of the regression equation $\hat{Y}=29,3747+0,6820 \mathrm{X}_{1}+0,2357 \mathrm{X}_{2}-0,3449$ $X_{3}$. The relative contribution of variable $X_{1}$ by $70.2356 \%$, of the variable $X_{2}$ by $11.6737 \%$ and of the variable $\mathrm{X}_{3}$ by $18.0907 \%$. The coefficient of multiple determination by 0.3026 with the effective contribution of variable $X_{1}$ by $21.25667 \%$, of variable $X_{2}$ by $3.53303 \%$ and of the variable $X_{3}$ by $5.47512 \%$.
\end{abstract}

Keywords: numerical ability, mathematical connections ability, and classmates learning interactions.

\section{INTRODUCTION}

Education is a very important requirement in life, this means that every citizen has the right to get an education. Education can be obtained at schools or formal educational institutions, besides that, it can also be obtained in the family environment as well as the community environment and the environment of peers. According to Law No. 20 of 2003, Learning is a process of interaction between students and educators and learning resources in a learning environment. In a learning process, there is an interaction involving active students, both in terms of individuals and groups. In addition to interactions between students and educators, students with learning resources, there are also interactions between students and students.

Mathematics in education in Indonesia is an important subject. It can be seen that mathematics subjects are taught from the elementary, middle and high school / vocational levels. Even mathematics has been introduced to early childhood, even though the presentation of the material provided is still limited to numerical recognition, and counting. But in reality, mathematics is still a subject that is not liked by many students, this is due to the perception that mathematics is one of the difficult and boring lessons. This is because the characteristics of mathematics itself are abstract, especially for students and to master mathematics requires perseverance, tenacity, and precision. To learn mathematics is not only enough to pay attention to what is conveyed by the teacher and read, but by practicing many questions. 
Understanding of mathematics learning according to Dienes quoted by Hudoyo, H (1979: 108) which says that learning mathematics involves hierarchical elements from higher concepts that are formed based on what has been formed before. So this assumption means that learning higher-level mathematical concepts is not possible if the preconditions preceded have not been studied. Definition of mathematics learning outcomes according to Uno, Hamzah (2009: 139), Mathematical learning outcomes are the results of activities from learning mathematics in the form of knowledge as a result of the treatment or learning done by students. Or in other words, student learning outcomes on mathematics subjects are what students get from the learning process. Based on data retrieval conducted at SMAN 2 Banguntapan in Bantul Regency, the mathematics scores of class XI IPA students in the Odd Semester 2015/2016 Academic Year are many. not complete. This proves that there are still many students who have difficulty learning mathematics.

The definition of numerical ability according to Siswoyo (2011: 121) is the ability of students to use numbers effectively and think logically. Numerical ability contains a person's ability to think inductively and deductively, think according to the rules of logic, understand and analyze patterns of numbers, and solve problems by using thinking skills. "When students are given a question of operations, calculate multiplication and division when learning the subject matter of Opportunity, most students need a relatively long time to complete it. Students still need guidance from teachers and other students whose numeracy skills are better for completing problems in calculating multiplication and division operations. Therefore it is assumed that student learning outcomes are low due to students' numerical abilities.

In learning mathematics there are five basic mathematical abilities according to NCTM in Sugiman (2008: 1) stated that there are five basic mathematical abilities which are standards namely problem solving (problem-solving), reasoning and evidence (reasoning and proof), communication (communication) connections, and representations. Besides, NCTM in Sugiman (2008: 2) also stated that "If students can associate mathematical ideas, their mathematical understanding will be deeper and longer-lasting because they can see the linkages between topics in mathematics, with contexts other than mathematics, and with everyday life experiences. Most students still cannot understand the interrelationships between mathematical concepts. Students often experience difficulties in problemsolving because they do not know the interrelationships between concepts. Seen when students cannot solve trigonometry questions in sine rule teaching materials and rules of cosmetics in the area of a triangle. Because students assume that each concept stands alone, students have difficulty in solving the problem.

Middle school students like to hang out with other teenagers, especially those of the same age. So is the relationship between adolescents in school, especially in the classroom, because in the class the age of students is relatively the same. According to Slavin, Robert E. (2009: 4-5), In the classroom, students are expected to help each other, discuss each other and argue to hone the knowledge they have mastered at that time and close the gaps in their respective understandings. Interactions like this can give rise to an attitude of acceptance towards classmates who are weak in academics, increase self-confidence, grow awareness that students need to learn to think and solve problems. In this study, the interaction in question is mutual, mutual discussion and arguing with each other in mathematics.

\section{METHODS}

This research is quantitative. This research was carried out in SMA N 2 Banguntapan, Bantul Regency with the research subject were students of class XI IPA even semester 2015/2016 academic year. The population in this study were students of class XI IPA 1, XI IPA 2, XI IPA 3, and XI IPA 4 SMA N 2 Banguntapan Bantul Regency 2015/2016 academic year. In this study the sampling technique using random sampling techniques for the class is taking subjects from population classes conducted randomly, sampling is done by drawing class names. Obtained class XI IPA 3 with 27 students as the research sample. Here's the research design: 


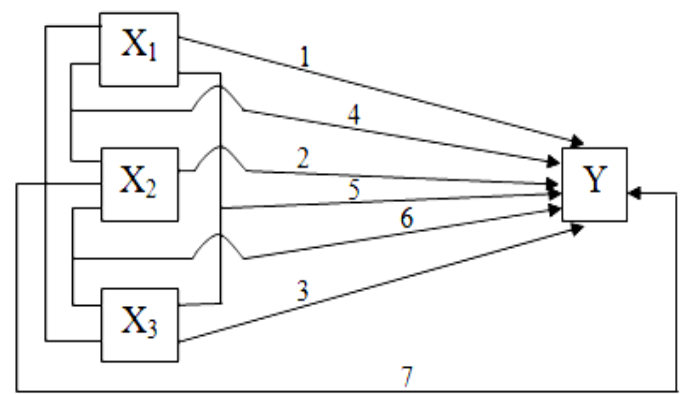

Picture I. Relationship between Variables X and Y in Research

Information :

$\mathrm{X}_{1}$ : the numeric ability

$\mathrm{X}_{2}$ : mathematical connection ability

$\mathrm{X}_{3}$ : classmates' learning interactions

Y: mathematics learning outcomes

According to Arikunto, Suharsimi (2013: 203), Research instruments are tools or facilities used by researchers in describing data so that work is easier and the results are better in the sense of faster, complete and systematic so that it is easier to process. The types of instruments used in this study were questionnaires and tests. The questionnaire consisted of classmates' learning interaction questionnaires, while the tests consisted of numerical ability tests, mathematical connection ability tests, and tests of mathematics learning outcomes. The test statistic used is the t-test, namely:

Information:

$$
t_{\text {count }}=\frac{r \sqrt{n-2}}{\sqrt{1-r^{2}}}
$$

$\mathrm{r} \quad=$ correlation coefficient

$\mathrm{n} \quad=$ Number of samples

(Khasanah, Uswatun, 2014: 60)

The null hypothesis pair $\left(\mathrm{H}_{0}\right)$ and its counterpart $\left(\mathrm{H}_{1}\right)$ for testing hypotheses with the t-test is:

1) First Hypothesis

$H_{0.1}: \rho \leq 0$

$H_{1.1}: \rho>0$

$H_{0.1}$ : There is no positive and significant relationship between numerical ability and the mathematics learning outcomes of students class XI IPA in even semester of SMAN 2 Banguntapan in Academic Year 2015/2016

$H_{1.1}$ : There is a positive and significant relationship between numerical ability and the mathematics learning outcomes of students class XI IPA in even semester of SMAN 2 Banguntapan in Academic Year 2015/2016

2) The second hypothesis

$H_{0.2}: \rho \leq 0$

$H_{1.2}: \rho>0$

$H_{0.2}$ : There is no positive and significant relationship between mathematical connection ability and the mathematics learning outcomes of students class XI IPA in even semester of SMAN 2 Banguntapan in Academic Year 2015/2016

$H_{1.2}$ : There is a positive and significant relationship between the ability to make mathematics and the mathematics learning outcomes of students class XI IPA in even semester of SMAN 2 Banguntapan in Academic Year 2015/2016

3) The third hypothesis

$H_{0.3}: \rho \leq 0$

$H_{1.3}: \rho>0$ 
$H_{0.3}$ : There is no positive and significant relationship between the learning interactions of classmates and the mathematics learning outcomes of students class XI IPA in even semester of SMAN 2 Banguntapan in Academic Year 2015/2016

$H_{1.3}$ : There is a positive and significant relationship between the learning interactions of classmates and the mathematics learning outcomes of students class XI IPA in the even semester of SMAN 2 Banguntapan in Academic Year 2015/2016.

The second test statistic is to use the $-\mathrm{F}$ test as follows:

Information:

$$
F=\frac{R^{2}(n-k-1)}{\left(1-R^{2}\right) k}
$$

$F$ : The value of $\mathrm{F}$ regression line

$R^{2}$ : Double coefficient of determination

$n$ : Sample size

$k$ : Number of independent variables

(Khasanah, Uswatun, 2014: 110)

The null hypothesis pair $\left(\mathrm{H}_{0}\right)$ and its counterpart $\left(\mathrm{H}_{1}\right)$ for testing the hypothesis with the F-test is:

1) The fourth hypothesis

$H_{0.4}: b_{i}=0$

$H_{1.4}: b_{i} \neq 0$

$H_{0.4}$ : There is no positive and significant relationship between numerical ability and mathematical connection ability with the mathematics learning outcomes of students class XI IPA in even semester of SMAN 2 Banguntapan in Academic Year 2015/2016.

$H_{1.4}$ : There is a positive and significant relationship between numerical ability and mathematical connection ability with the mathematics learning outcomes of students class XI IPA in even semester of SMAN 2 Banguntapan in Academic Year 2015/2016.

2) The fifth hypothesis

$H_{0.5}: b_{i}=0$

$H_{1.5}: b_{i} \neq 0$

$H_{0.5}$ : There is no positive and significant relationship between numerical abilities and classmates' learning interactions with the mathematics learning outcomes of students class XI IPA in even semester of SMAN 2 Banguntapan in Academic Year 2015/2016.

$H_{1.5}$ : There is a positive and significant relationship between numerical abilities and classmates' learning interactions with the mathematics learning outcomes of students class XI IPA in even semester of SMAN 2 Banguntapan in Academic Year 2015/2016.

3) Sixth hypothesis

$H_{0.6}: b_{i}=0$

$H_{1.6}: b_{i} \neq 0$

$H_{0.6}$ : There is no positive and significant relationship between mathematical connection skills and classmates' learning interactions with the mathematics learning outcomes of students class XI IPA in even semester of SMAN 2 Banguntapan in Academic Year 2015/2016.

$H_{16}$ : There is a positive and significant relationship between mathematical connection skills and classmates' learning interactions with the mathematics learning outcomes of students class XI IPA in even semester of SMAN 2 Banguntapan in Academic Year 2015/2016.

The third test statistic is to use the $-\mathrm{F}$ test as follows:

$$
F=\frac{R^{2}(n-m-1)}{m\left(1-R^{2}\right)}
$$


Information :

$F$ : The value of $\mathrm{F}$ regression line

$R^{2}$ : coefficient of multiple determination

$m$ : number of independent variables

$n$ : number of samples

(Khasanah, Uswatun, 2014: 154)

The null hypothesis pair (H0) and its counterpart (H1) for testing the hypothesis with the F-test is the seventh hypothesis.

$H_{0.7}: b_{i}=0$

$H_{1.7}: b_{i} \neq 0$

$H_{0.7} \quad$ : There is no positive and significant relationship between numerical ability, mathematical connection ability and classmates' learning interactions with the mathematics learning outcomes of students class XI IPA in even semester of SMAN 2 Banguntapan in Academic Year 2015/2016.

$H_{1.7} \quad$ : There is a positive and significant relationship between numerical ability, mathematical connection ability and classmates' learning interactions with the mathematics learning outcomes of students class XI IPA in even semester of SMAN 2 Banguntapan in Academic Year $2015 / 2016$.

\section{RESULTS AND DISCUSSION}

1. The results of the first hypothesis test are that there is a positive and significant relationship of numerical abilities with the learning outcomes of mathematics. This shows the better the numerical ability of students, the better in solving mathematical problems, then the results of good mathematics learning will be obtained. In this study linear lines were obtained $\hat{Y}=10,9259+0,7917 \mathrm{X}_{1}$ with a regression coefficient of 0.7917 . This means that every increase of one unit $X_{1}$ results in 0.7917 increase Y. Obtained also the correlation coefficient $(r)$ of 0.6218 which means that the increase or decrease in numerical abilities can be explained by the variation in mathematics (Y) learning outcomes explained by numerical abilities $\left(\mathrm{X}_{1}\right)$.

2. The second hypothesis test results are a positive and significant relationship between mathematical connection skills and mathematics learning outcomes. This shows the better the students' mathematical connection skills, the better the learning outcomes of mathematics. In this study, linear lines were obtained $\hat{Y}=43,8666+0,4564 X_{2}$, with a regression direction coefficient of 0.4564 , meaning that every increase of one unit $\mathrm{X}_{2}$ results in 0.4564 increase in $\mathrm{Y}$. Obtained also a simple correlation coefficient $(r)$ of 0.33172 which means that increasing or decreasing mathematical connection ability can be explained that there are variations in results mathematics learning $(\mathrm{Y})$ is explained by mathematical connection skills $\left(\mathrm{X}_{2}\right)$.

3. The third hypothesis test results are there is a positive and significant relationship between classmates' learning interactions with mathematics learning outcomes. This shows that better student learning interactions in the classroom, the better the learning outcomes of mathematics. In this study linear lines were obtained $\hat{Y}=21,529+0,724 \mathrm{X}_{3}$, with a regression direction coefficient of 0.7242 , meaning that every increase of one unit X3 results in a 0.7242 increase in Y. Obtained also a simple correlation coefficient $(r)$ of 0.4244 which means that the increasing or decreasing learning interactions of classmates can be explained that there are variations in mathematics learning outcomes $(\mathrm{Y})$ explained by classmates' learning interactions $\left(\mathrm{X}_{3}\right)$.

4. The fourth hypothesis test results are a positive and significant relationship between numerical ability and mathematical connection ability with the learning outcomes of mathematics. This shows that the better numerical ability and mathematical connection skills, the learning outcomes of mathematics will also be good. In the study obtained multiple linear regression lines $\hat{Y}=9,6848+$ 
$0,7725 X_{1}+0,0416 X_{2}$. Also obtained multiple correlation coefficient $(\mathrm{R})$ of 0.62238 which means that the increasing or decreasing numerical ability and mathematical connection ability can be explained that the variation in mathematics learning outcomes $(\mathrm{Y})$ is explained by numerical abilities $\left(\mathrm{X}_{1}\right)$ and mathematical connection skills $\left(\mathrm{X}_{2}\right)$.

5. The fifth hypothesis test results are a positive and significant relationship between numerical abilities and classmates' learning interactions with mathematics learning outcomes. This shows the better numerical abilities and learning interactions of classmates, the mathematics learning outcomes will also be good. In the study obtained multiple linear regression lines $\hat{Y}=-14,283+0,693 \mathrm{X}_{1}+$ $0,454 \mathrm{X}_{3}$. Obtained also multiple correlation coefficient $(\mathrm{R})$ of 0.672 which means that increasing or decreasing numerical abilities and classmates 'learning interactions can be explained that the variation in mathematics learning outcomes $(\mathrm{Y})$ is explained by numerical abilities $\left(\mathrm{X}_{1}\right)$ and classmates' learning interactions $\left(\mathrm{X}_{3}\right)$

6. The sixth hypothesis test results are a positive and significant relationship between mathematical connection skills and classmates' learning interactions with mathematics learning outcomes. This shows that the better the mathematical connection skills and classmates' learning interactions, the better the learning outcomes of mathematics. In the study obtained multiple linear regression lines $\hat{Y}=9,6345+0,3060 X_{2}+0,6077 X_{3}$. Obtained also multiple correlation coefficient $(\mathrm{R})$ of 0.47425 which means that the increase or decrease between mathematical connection abilities and classmates' learning interactions can be explained that there are variations in mathematics learning outcomes $(\mathrm{Y})$ which are explained between mathematical connection skills $\left(\mathrm{X}_{2}\right)$ and interactions study classmates $\left(\mathrm{X}_{3}\right)$.

7. The seventh hypothesis test results are a positive and significant relationship between numerical abilities, mathematical connection skills, and classmates' learning interactions with mathematics learning outcomes. This shows that the higher numerical abilities, mathematical connection skills, and classmates' learning interactions, the better the learning outcomes of mathematics. In the study obtained multiple linear regression lines $\hat{Y}=-13,596858225+0,709291915 X_{1}-$ $0,039010253 X_{2}+0,462962917 X_{3}$. Obtained also multiple correlation coefficient (R) of 0.6724 and multiple determination coefficients $\left(\mathrm{R}^{2}\right)$ between numerical ability, mathematical connection ability, and classmates' learning interactions with mathematics learning outcomes of 0.45217 which means that numerical abilities increase or decrease, ability mathematical connections, and classmates 'learning interactions can be explained that the variation in mathematics learning outcomes $(Y)$ is explained by numerical abilities $\left(\mathrm{X}_{1}\right)$, mathematical connection skills $\left(\mathrm{X}_{2}\right)$ and classmates' learning interactions $\left(\mathrm{X}_{3}\right)$. The relative contribution (SR) of $\mathrm{X}$ variable is $73.555 \%$, relative contribution (SR) of $\mathrm{X}_{2}$ variable is $1.997 \%$ and the relative contribution (SR) of $\mathrm{X}_{3}$ variable is $24.448 \%$, this means that from the independent variables studied, the relationship of numerical ability is $73.555 \%$, the relationship of mathematical connection ability is $1.997 \%$ and classmates' learning interactions are $24.448 \%$ with the results of mathematics learning. The effective contribution (SE) of X variable was $33.259 \%$, the effective contribution (SE) of the $\mathrm{X}_{2}$ variable was $0.903 \%$ and the effective contribution (SE) of the $\mathrm{X}_{3}$ variable was $11.055 \%$, this means that numerical ability was related to $33.259 \%$, mathematical connection ability $0.903 \%$ and classmates' learning interactions relate to $11.055 \%$, with mathematics learning outcomes.

\section{CONCLUSION}

Based on the results of the research and discussion as described in CHAPTER IV, the research conclusions can be drawn in the seventh hypothesis as follows:

There is a positive and significant relationship between numerical ability, mathematical connection skills, and classmates' learning interactions with the mathematics learning outcomes of students of class XI IPA even semester of SMAN 2 Banguntapan Kabubaten Bantul 2015/2016 Academic Year. This is indicated by the $\mathrm{F}$ test, is $F_{\text {cal }}>F_{\text {table }}$ with details $F_{\text {cal }}=6,32795$ and $F_{\text {table }}=3,028$. With a multiple correlation 
coefficient $(R)$ of 0.6724 and a large multiple determination coefficient $\left(R^{2}\right)=0.45217$ with a regression equation $\hat{Y}=-13,597+0,709 X_{1}-0,039 X_{2}+0,463 X_{3}$. The relative contribution (SR) of variable $\mathrm{X}$ is $73.555 \%$, the relative contribution (SR) of the $\mathrm{X}_{2}$ variable is $1.997 \%$ and the relative contribution (SR) of the $\mathrm{X}_{3}$ variable is $24.448 \%$, this means that from the independent variables studied, the relationship of numerical abilities is $73.555 \%$, the relationship of mathematical connection ability is $1,997 \%$ and the relationship between classmates' learning interactions is $24,448 \%$, with the results of mathematics learning. The effective contribution (SE) of the $\mathrm{X}$ variable was $33.259 \%$, the effective contribution (SE) of the $\mathrm{X}_{2}$ variable was $0.903 \%$ and the effective contribution (SE) of the $\mathrm{X}_{3}$ variable was $11.055 \%$, this means that the numerical ability is $33.259 \%$, mathematical connection ability related to $0.903 \%$ and classmates' learning interactions related to $11.055 \%$, with the results of learning mathematics. This means that students 'mathematics learning outcomes are influenced by numerical abilities, mathematical connection skills, and classmates' learning interactions by $45.217 \%$ while $54.783 \%$ is influenced by other factors not discussed in this study.

\section{REFERENCES}

Depdikbud.2003.Undang-undang Republik Indonesia No 20 Tahun 2003.Jakarta: BP. Cipta

Hudoyo, H. 1997. Pengembangan Kurikulum Matematika dan Pelaksanaanya di Depan Kelas. Surabaya: Usaha Nasional

Khasanah, Uswatun. 2014. Analisis Regresi. Yogyakarta : UAD Press

Siswoyo. 2011. Ilmu Pendidikan. Yogyakarta: UNY Press

Slavin, Robert E. 2009. Cooperative Learning. Bandung: Penerbit Nusa Media

Sugiman. 2008. "Kemampuan Matematik dalam Pembelajaran Matematika di Sekolah Menengah Pertama". http: // staff.uny.ac.id / sites / default / files / 131930135 / 2008_Koneksi_Mat.pdf. Diunduh tanggal : 6 Juni 2015

Uno, Hamzah. 2009. Model Pembelajaran. Jakart $a$ : Bumi Angkasa 